\title{
\begin{tabular}{|c|c|}
\hline Jurnal Abdimas Saintika & $\begin{array}{l}\text { e-ISSN : 2715-4424 } \\
\text {-ISSN :2746-797X }\end{array}$ \\
\hline
\end{tabular}
}

\section{PELATIHAN UPAYA PENCEGAHAN PENYEBARAN COVID-19 KEPADA KADER KESEHATAN DI DUSUN PRINGWULUNG CONDONG CATUR DEPOK SLEMAN}

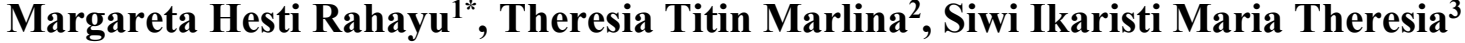 \\ 1,2,3Program Studi Diploma Tiga Keperawatan, Stikes Panti Rapih \\ *Email : margareta.hestirahayu@stikespantirapih.ac.id
}

\begin{abstract}
ABSTRAK
Covid-19 menjadi permasalahan pandemic global, tingkat penyebaran dan keparahan menjadi menghawatirkan dari virus tersebut. Kabupaten Sleman merupakan salah satu wilayah yang mengalami transmisi lokal. Penularan virus Corona dapat terjadi dengan mudah dari satu orang ke orang lain. Tujuan kegiatan ini adalah untuk meningkatkan pengetahuan warga masyarakat Padukuhan Pringwulung tentang pencegahan penyebaran Covid-19. Metode yang digunakan adalah penyuluhan, pelatihan dan diskusi. Kegiatan ini menghasilkan peningkatan pengetahuan dan kemampuan untuk membuat face shield. Kesimpulan: Kader mampu memahami tentang pencegahan penyebarab Covid-19 dan mampu membuat face shield secara mandiri.
\end{abstract}

Kata Kunci: pencegahan penyebaran, Covid-19, pengetahuan

\section{ABSTRACT}

Covid-19 is a global pandemic problem, the level of spread and severity of the virus is worrying. Sleman Regency is one of the areas experiencing local transmission. Corona virus transmission can occur easily from person to person. The purpose of this activity is to increase the knowledge of the residents of the Padukuhan Pringwulung community about preventing the spread of Covid-19. The methods used are health education, training and discussion. This activity resulted in increased knowledge and the ability to make face shields. Conclusion: Cadres are able to understand about preventing the spread of Covid-19 and are able to make face shields independently.

Keywords: prevention of spread, Covid-19, knowledge

\section{PENDAHULUAN}

Badan Kesehatan Dunia (WHO) menetapkan bahwa wabah virus Corona sebagai pandemi global menyebar hampir ke seluruh negara di dunia. Virus SARSCoV-2 merupakan penyebab penyakit Covid-19 ini menyebar sejak akhir Desember 2019 dari Wuhan, China hingga ke hampir semua benua di dunia (Azzanela, 2020, Widyaningrum, 2020). Indonesia merupakan salah satu dari 185 negara di dunia yang terjankit transmisi lokal dan merupakan urutan ke-18 di dunia dengan jumlah kasus terkonfirmasi Covid-19. Sampai saat ini 24 Februari 2021 dari sumber Worldometer (2021) kasus yang terkonfirmasi di global mencapai 112,638,446 dengan kasus kematian mencapai 2,21\% atau 2,495,339. Indonesia sebagai negara yang terdampak Covid-19 pun juga juga memililki kasus yang terkonfirmasi mencapai 1,298,608 dengan angka kematian mencapai 2,69\% atau 35,014 kasus kematian. Nilai kematian secara prosentase di Indonesia hampir menyamai prosentase kematian di dunia. Yogyakarta sebagai salah satu propinsi di Indonesa memiliki jumlah kasus yang terkonfirmasi positif pada tanggal 23 Februari 2021 dari sumber resmi Diskominfo Yogyakarta, (2021) yaitu 26.822 dan terdapat 652 kasus dengan kematian (2,43\%). Kabupaten Sleman merupakan salah satu wilayah 


\section{Jurnal Abdimas Saintika}

Volume 3 Nomor 1 | https://jurnal.syedzasaintika.ac.id

yang mengalami transmisi lokal dengan angka kematian tertinggi yaitu 154 orang diantara kabupaten lain di Propinsi Daerah Istimewa Yogyakarta.

Penularan virus Corona terjadi dari orang ke orang dan dapat terjadi melalui droplet yang berasal dari batuk dan bersin, kontak pribadi misalnya berjabat tangan, menyentuh benda yang terdapat virus dan kemudian menyentuh bagian wajah (Dzulfaroh, 2020). Namun demikian berbagai tindakan dapat dilakukan untuk mengurangi resiko penularan virus Corona tersebut yaitu dengan rajin mencuci tangan, memakai masker, melakukan pola hidup bersih dan sehat, menghindari kontak fisik dan sosial dengan cara tinggal di rumah. Kurangnya pengetahuan dan pemahaman serta ketidakpedulian masyarakat terhadap hal tersebut dapat menghambat usaha untuk menurunkan angka kejadian ataupun mencegah penularan. Sebagian daerah Padukuhan Pringwulung desa Condong Catur Kecamatan Depok dihuni oleh mahasiswa dan warga yang memiliki mobitas tinggi. Sebagai salah satu bentuk kegiatan untuk mendukung gerakan pencegahan penularan virus Corona dan menurunkan laju angka kejadian tersebut, maka dirasa perlu untuk meningkatkan pengetahuan warga melalui kader Kesehatan yang ada di Padukuhan Pringwulung desa Condong Catur Kecamatan Depok.

\section{HASIL DAN PEMBAHASAN}

Kegiatan ini dilakukan pada tanggal 1- 20 Agustus 2020 dengan hasil sebagau berikut:

\section{METODE}

Tujuan kegiatan ini adalah meningkatkan pengetahuan kader Kesehatan tentang pencegahan penyebaran Covid-19

Isi kegiatan ini adalah memberikan pelatihan dan pengetahuan tentang pencegahan penyebaran Covid-19

Sasaran kegiatan ini adalah kader Kesehatan di Padukuhan Pringwulung desa Condong Catur Kecamatan Depok.

Strategi kegiatan ini adalah

a. Membentuk whatsapp grup (WAG) dengan kader yang beranggotakan kader

b. Menyampaikan rencana kegiatan

c. Memberikan pre test

d. Menyampaikan materi dalam bentuk Power point bersuara dan video

e. Memberikan bahan habis pakai (BHP) untuk pembuatan face shield dan memberikan masker

f. Mengajari cara pembuatan face shield menggunakan video

g. Kader membuat face shield secara mandiri

h. Kader mendokumentasi hasil face shield yang dibuat dalam bentuk foto dan dikirimkan melalui WAG serta instagram bagi yang punya.

i. Melakukan post tes dan evaluasi kegiatan

Karakteristik Peserta

Peserta kegiatan PKM ini adalah ibu kader di Padukuhan Pringwulung sebanyak $8 \mathrm{ibu}$. 


\section{Jurnal Abdimas Saintika}

Volume 3 Nomor 1 | https://jurnal.syedzasaintika.ac.id

Tabel 1

Karakteristik Peserta Pelatihan $n=8$

\begin{tabular}{lcc}
\multicolumn{1}{c}{ Item } & N & $\mathbf{\%}$ \\
\hline Usia & & \\
$20-29$ & 1 & 12,5 \\
$30-39$ & 3 & 37,5 \\
$40-49$ & 2 & 25 \\
$50-59$ & 2 & 25 \\
Pendidikan & & \\
SLTP & 2 & 25 \\
SLTA & 4 & 50 \\
PT & 2 & 25 \\
Lama menjadi kader & & \\
$<1$ tahun & 2 & 25 \\
1-3 tahun & 2 & 25 \\
$>3$ tahun & 4 & 50 \\
Sumber informasi & & \\
TV & 7 & 87,5 \\
Koran & 5 & 62,5 \\
Internet & 8 & 100 \\
Media social & 8 & 100 \\
Petugas kesehatan & 5 & 62,5 \\
\hline S
\end{tabular}

Sumber: Data Primer (2020)

\section{Hasil Pre tes}

Pre tes pada ibu kader di Padukuhan Pringwulung dilakukan sebelum mendapatkan materi penyuluhan.

Tabel 2

Hasil Pre Tes pada ibu kader di Padukuhan Pringwulung $n=8$

\begin{tabular}{|c|c|c|}
\hline Kategori & n & $\%$ \\
\hline Baik & 8 & 100 \\
\hline Cukup & 0 & 0 \\
\hline Kurang & 0 & 0 \\
\hline Total & 8 & 100 \\
\hline
\end{tabular}

Sumber: Data Primer

\section{Hasil Post tes}

Post tes pada ibu kader di Padukuhan Pringwulung dilakukan sesudah mendapatkan materi penyuluhan.

Tabel 4.4

Hasil Post Tes pada ibu kader di Padukuhan Pringwulung $\mathbf{n}=8$

\begin{tabular}{lcc}
\hline Kategori & n & \% \\
Baik & 8 & 100 \\
Cukup & 0 & 0 \\
Kurang & 0 & 0 \\
\hline Total & 8 & 100 \\
\hline
\end{tabular}

Sumber: Data Primer 


\section{Jurnal Abdimas Saintika}

Volume 3 Nomor 1 | https://jurnal.syedzasaintika.ac.id

Berdasarkan hasil diatas bahwa tingkat pengetahuan ibu sebelum dan sesudah diberikan penyuluhan masuk dalam kategori baik.

Pemberian informasi mengenai pencegahan COVID-19 melalui berbagai media dan dengan metode yang tepat, sebagai upaya untuk melakukan physical distancing terus dilakukan secara terusmenerus oleh semua pihak. Padukukan Pringwulung, sebagai salah satu daerah di kecamatan Depok Kabupaten Sleman dengan angka kejadian COVID-19 dan kematian tertinggi di DIY (DIY, 2021), menjadi sasaran untuk melakukan pengabdian kepada masyarakat dalam pencegahan penyebaran COVID-19.

Bentuk pengabdian yang dilakukan adalah melakukan memberikan pendidikan kesehatan tentang pencegahan penyebaran COVID-19 kepada Kader Kesehatan di rumah dan tempat umum, penggunaan masker dan bahan masker yang tepat, dan pelatihan membuat face shield. Pelatihan dilakukan dengan menggunakan media WhatsApp Group. Metode pelatihan dengan pemutaran Video dan Power Point untuk memberikan materi dan diskusi. Penggunaan WAG ini merupakan salah satu cara untuk melakukan physical distancing dalam pencegahan penyebaran COVID-19. Pemilihan metode ini didasarkan pilihan peserta kader karena dirasa lebih mudah dalam penggunaannya karena mudah dibaca ulang dan tidak menggunakan sinyal internet yang berlebihan. Hal ini sesuai dengan penelitian Yulianto, Cahyani \& Silvianita (2020) bahwa penggunaan WhatApp Group menajdi pilihan 98\% mahasiswa dalam perkuliahan daring di tengan pandemic COVID-19 dibandingkan dengan penggunaan aplikasi Zoom.

Proses pelatihan dilakukan dengan diawali pre-test - pemberian materi diskusi - post-test. Soal pre dan post tes berjumlah 20 soal. Hasil pre dan post tes pada ibu kader Padukuhan Pringwulung dalam kategori baik (100\%), hal ini kemungkinan dapat disebabkan oleh motivasi yang tinggi dari ibu untuk mendapatkan informasi tentang Penyakit Virus Corona dan penyebarannya. Data demografi yang lain menunjukkan bahwa lingkungan atau area Pringwulung termasuk dalam area perkotaan dimana terletak $7.1 \mathrm{~km}$ dari Ibu Kota Provinsi Daerah Istimewa Yogyakarta dan terdapat terdapat perguruan tinggi di area tersebut sehingga termasuk dalam area urban (perkotaan) (Bappeda Sleman, 2021). Kondisi ini juga mendukung dalam peningkatan pengetahuan penduduk sekitar, dimana lingkungan juga menjadi factor pengetahuan seseorang (Budiman \& Riwanto, 2013). Selain itu, data karakteristi responden atau kader yang diberikan pelatihan semuanya $100 \%$ adalah wanita dan berusia diatas 20 tahun. Menurut Ferdous, dkk, (2020) bahwa social demografi yaitu jenis kelamin wanita, tingkat usia 21 tahun keatas dan tinggal di daerah urban memiliki sikap yang positif untuk melakukan praktik pencegahan COVID19. Maka dengan hasil pengetahun yang baik ini diharapkan mempunyai dampak positif di dalam menyikapi dan berperilaku dalam mencegah penyebaran COVID-19 yang saat ini masih berlangsung di daerah Pringwulung, Condong Catur, Depok Sleman.

\section{SIMPULAN}

Berdasarkan hasil kegiatan pelatihan dan penyuluhan pencegahan penyebaran Covid-19, kader kesehatan mampu

a. Menjelaskan pengertian Covid-19

b. Menjelaskan cara pencegahan dan penyebaran Covid-19

c. Membuat faceshield secara mandiri

\section{DAFTAR PUSTAKA}

Azanela. Luthfia Ayu. (2020). Berikut Ini 7 Negara yang Telah Melalui Masa Puncak Pandemi Corona. Diakses dari 


\section{Jurnal Abdimas Saintika}

Volume 3 Nomor 1 | https://jurnal.syedzasaintika.ac.id

https:/www.kompas.com/tren/rea d/2020/05/09/183000065/berikutini-7-negara-yang-telah-melaluimasa-puncak-pandemi-corona.

Bappeda Sleman. (2021, Januari 7). Peta Wilayah. Retrieved from Kapanewon Depok: https://depokkec.slemankab.go.id/ profile/peta-wilayah

Budiman \& Riyanto A. 2013. Kapita Selekta Kuisioner Pengetahuan Dan Sikap Dalam Penelitian Kesehatan. Jakarta: Salemba Medika pp 66-69.

Diskominfo. (2021, Februari 23). Data Harian Covid-19 D.I Yogyakarta. Retrieved Februari 24, 2021, from Pemerintah Daerah Istimewa Yogyakarta:https://corona.jogjapr ov.go.id/

DIY, P. D. (2021, Januari 7). Data Terkait COVID-19 di D.I. Yogyakarta. Retrieved from YOGYAKARTA TANGGAP COVID-19:

https://corona.jogjaprov.go.id/data -statistik

Dzulfaroh, Ahmad Naufal. (2020). Cara Penularan Virus corona dan alasan pentingnya social distancing. Diakses dari https//www.kompas.com/tren/read /2020/03/19/064600465/carapenularan-virus-corona-danalasan-pentingnya-socialdistancing

Ferdous, M Z., Islam, M S., Sikder, M T., Mosaddek, A S M., Valdivia, J A., Z., \& Gozal, D. (2020). Knowledge, attitude, and practice regarding COVID-19 outbreak in
Bangladesh: an online based cross-sectional study. PLOS ONE, $1-17$.

Kementerian Kesehatan RI. (2020). COVID-19. Infeksi Emerging. Media Informasi Terkini Penyakit Infeksi Emerging. Diakses dari https://covid19.kemkes.go.id/

WHO. (2020, July 20). World Health Organization. Retrieved from WHO Coronavirus Disease (COVID-19) Dashboard: https://covid19.who.int/

Worldometer. (2021, Februari 24). COVID-19 CORONAVIRUS PANDEMIC. Retrieved Februari 24, 2021, from Wroldometer: https://www.worldometers.info/co ronavirus/

Widyaningrum, Gita Laras. (2020). WHO tetapkanCOVID-19 sebagai pandemi global, apa maksudnya?. Diakses dari https://nationalgeographic.grid.id/ $\mathrm{read} / 132059249 /$ who-tetapkanCOVID-19-sebagai-pandemiglobal-apa-maksudnya

Yulianto, E., Cahyani, P D., \& Silvianita, S. (2020). Perbandingan hehadiran sosial dalam pembelajaran daring menggunakan whatsapp group dan webinar zoom berdasarkan sudut pandang pembelajar pada masa pandemic COVID-19. Jurnal Riset Teknologi dan Inovasi Pendidikan (JARTIKA), 331-341. 